\title{
Feedback Environment and Job Motivation among the Middle Leaders of Educational Organizations
}

\author{
Ying-Leh Ling (Corresponding author) \\ School of Educational Studies, Universiti Sains Malaysia \\ 11800 USM, Penang, Malaysia \\ E-mail: lingyingleh@gmail.com \\ Abdul Ghani Kanesan Abdullah \\ School of Educational Studies, Universiti Sains Malaysia \\ 11800 USM, Penang, Malaysia \\ E-mail:agk@usm.my \\ Fairuz Ismail \\ Malim Nawar Secondary School \\ 31700 Malim Nawar, Perak, Malaysia \\ E-mail: fais71@hotmail.com
}

Received: September 18, 2015 Accepted: September 28, 2015 Published: October 12, 2015

doi:10.5296/jet.v3i1.8415 URL: http://dx.doi.org/10.5296/jet.v3i1.8415

\begin{abstract}
This study aims to identify the level of feedback environment and job motivation among the school middle leaders. Basically, the objective of this study is to determine whether is there any significant difference between feedback environment and job motivation with gender group in the study. Moreover, this study also identifies whether is there any relationship between feedback environment and job motivation. Therefore, 63 subject coordinators of fifteen secondary schools in South Kinta district which is located in Perak Darul Ridzuan, Malaysia had participated in this study. Data for this study were collected through a questionnaire which was adapted from past researchers. Descriptive analysis was done using frequency and standard deviation while inferential analysis was carried out using Spearman correlation test and Mann-Whitney U test. Results have shown that the level of feedback environment and job motivation are high. In addition, the study also showed that feedback environment has a significant and positive relationship with job motivation. Accordingly, the results found that there is no significant difference for the feedback environment and job motivation with gender group. In terms of its implications, the school leaders in educational organizations should enhance the skills, knowledge and credibility in providing constructive
\end{abstract}


feedback and consistency for shaping and enhancing self-efficacy among their followers. Generating useful feedback and help should be emphasized in the working environment by the principals in order to increase the motivation of the school middle leaders in achieving the targets set.

Keywords: Feedback environment, Job motivation, School middle leaders

\section{Introduction}

Each organization has a leader who acts as a catalyst in driving his team to achieve the vision and mission set. However, the success of a particular education organization is not merely depends on the top leadership alone. In this context, the role played by the middle leaders should not be underestimated, as the middle leaders are relatively close to the followers. In the school context, the middle leaders in this study are the subject coordinators. They do not only ensure the continuity of the structure and the existing education system but they also act as the middle leaders. They are capable to move their subordinates, generally the teachers to turn to the organization so that they will be more sensitive and work together to address all the changes in our education system.

Some middle leaders in schools are more creative, innovative and effective in achieving the desired goals but there are also some who face many obstacles and difficulties before reaching the goal. In this case, the motivation factor is believed to be able to encourage individuals to act in order to achieve their goals. Motivation is often correlated with the achievement of excellence performance whether individual performance or organizational effectiveness. Hence, school leaders as the top leaders should focus on the aspects of motivation of the middle leaders because they are the key of success of the school and the human capital of the country.

In facing the upgrading of life paradigm in the 21 st century, school leaders must take the initiative to undertake the development of potential middle leaders, especially in the psychological aspect of the organization. In this case, the organization emphasized the psychological aspect in line with the opinion of Jex and Britt (2008) in which a leader should focus on his follower's psychology as it measures an individual behavior, specifically to identify how his followers influenced the organizational effectiveness. Therefore, educational organizations should play a role in a more comprehensive way and not just produce products to meet the needs of industrial markets. To ensure the quality of human capital generated, school leaders should focus on the input (feedback) and process (feedback environment) within the organization. Thus, in forming the middle leaders who are committed and motivated, setting up feedback environmental in the workplace should not be neglected. This is because the feedback at work is believed to have an effect on the formation of an individual's self-efficacy.

\section{Feedback Environment}

In the development of the organization environment that supports interaction feedback process in the organization, Levy's teams through research undertaken (Norris-Watts \& Levy, 2004; Rosen, Levy, \& Hall, 2006; Steelman, Levy, \& Snell, 2004) have emphasized feedback 
environment as the process of disseminating daily feedback between leaders and followers other than officially feedback sessions for performance evaluations conducted. In assessing feedback environment in the organization globally, focused on the perception of workers about the seven dimensions were made by Steelman et al. (2004). There are seven dimensions namely the reliability of feedback source, quality of feedback, feedback delivery, favorable feedback, unfavorable feedback, availability of feedback and encourage feedback seeking.

The reliability of feedback source responds to the level of expertise of feedback source. It means the feedback from (a) a person who has been observing the behavior of an individual, (b) the power to assess and (c) have a motive to provide a reliable feedback response which is more likely to influence the behavior of followers compared to the incompetent source of feedback in assessing the job behavior (Makiney \& Levy, 1998). Apart from that, Hattie and Timperly (2007) mentioned that quality feedback should be used to answer these three questions, (a) what are my goals? (b) What progress is being made towards the goals? (c) What activities should be implemented to achieve better progress?

Furthermore, the feedback deliver needs to learn to convey the message including the intention and attitude in the process of providing feedback. Aguinis, Gottfredson, and Joo (2012) has emphasized that feedback should be delivered by more constructive approach based on the strength of workers instead of their faults or weaknesses. This is because the feedback based on followers' workforce approach is believed to create a greater impact on employee's performance because it helps individuals to achieve the targets set. In addition, individuals will be satisfied with the feedback received if feedback is useful to them (Ilgen \& Moore, 1987). Favorable feedback in this study is seen as the frequency of employers responded positively to their followers. Positive feedback includes praise, encouragement and support given to the followers in order to succeed in their career.

In addition, unfavorable feedback is also seen as a negative feedback that is not favored by people. Geddes and Linnehan (1996) has identified the dimensions of positive feedback and negative feedback as two different constructs, (a) without instruction/without praise (recipients do not need a referral or praise for their progress) and (b) there is an instruction/guidance formed (received feedback during operation) with product-focused. Unfavorable feedback might be necessary to change the poor performance provided with the condition that poor performing employees are aware of the gap between desired performance and actual performance if they want to devote time and effort to minimise the gap (Ilgen \& Davis, 2000).

Availability of feedback source is important and valuable to build leaders through a challenging experience because access to feedback will help individuals to cope with various situations. It is also considered as a mechanism to facilitate learning. This statement was strengthened by Kluger and Denis (1996), in which access to feedback helps individuals to improve their self-awareness and has a more precise understanding of the efficiency and performance of themselves. Access to the experience and knowledge of leaders can be used to the maximum by encouraging the followers to seek feedback. William, Miller, Steelman and Levy (1999) emphasized that an important determinant of the frequency of feedback among the workers is 
the extent to which leaders encourage followers to get feedback. In this case, leaders must realize the role of each individual is to seek feedback actively. Thus, the behavior of search feedback will benefit both individuals and organizations (Yanagizawa, 2008).

\section{Self-Efficacy of Teaching}

Teaching is what is conveyed by educators to the students and learning is what is received by the students. Lessons will not be impressed if the teaching is not impressive. Thus, every educator must have the characteristics of an effective educator. One of the characteristics is by having self-efficacy of teaching. It is because the high self-efficacy of teaching is considered as an important element in influencing the achievement, attitudes, and effective student development. Bandura (1986) refers teacher self-efficacy as a belief in their ability to learn, perform on stage where behavior is required, arrange tasks, and obtain the desired results. It is clearly shown that demonstrating self-efficacy of teaching among the educators is more likely reflecting their expectations of their ability to bring positive changes on students' learning. This is in line with the views of Moore and Esselman (1992).

Self-efficacy of teaching does not only allow instructors to impart knowledge, but they can put a higher target on the students, easy to accept new ideas, try new teaching techniques, and has a high resistance to the new or difficult task while, the low teaching self-efficacy educators who will try to avoid facing the task of teaching as a challenge will have low aspirations, give-up easily and will feel the stress in their teaching duties. Tschannen-Moran and Hoy (2001) has established their instrument to measure teacher self-efficacy in three sub-scales such as efficacy for teaching strategies, efficacy for students' engagement, and efficacy for classroom management. Efficacy for teaching strategies refers to the strategies used by the teacher to make sure students understand what has been delivered. The strategy here refers to the forms of assessment used, the explanation given, questions asked, and alternatives in teaching. Moreover, efficacy for students' involvement also refers to the strategies used by the teachers to improve or promote the involvement of students in the classroom. The strategies used have helped to foster confidence in students towards their ability, to appreciate learning, and to motivate the students and the families involved in order to improve students' achievement. In addition, the efficacy of the classroom management refers to the teachers' ability in the classroom to take care of the learners in order to cope with the discipline problem, so that the supportive learning environment can be created in the classroom for students' learning.

\section{Job Motivation}

One of the school leaders' ability is to influence and motivate middle leaders to achieve the organizational objectives. With this motivation, it has triggered cooperation and therefore team spirit is formed to achieve organizational goals. The behavior of subordinates reflects their motivation to work. Overall, the basic model of motivation is related to three main elements, namely the need, satisfaction and behavior that mutually influence each other. If an individual has a need, thus he will try to get it for the sake of self-satisfaction, and people will change their behavior to achieve it. 
Motivation in general is the power that drives an individual to achieve an objective. Nurul Jalilah (2013) describes the concept of motivation based on the definition given by the former scientists, namely, (a) arising within oneself whether in the form of an impulse or instinct (b) based on the requirements or needs (c) a continuous process (d) cause someone to take action and (e) provide strength or energy to behave in particular to complete necessary requirements in a long time.

Wigfield and Guthrie (1997) has classified motivation into four categories, namely self-efficacy motivation, intrinsic motivation, extrinsic motivation and social motivation. Self-efficacy motivation is motivation arising from an individual who believes he can carry out his duties effectively (Chua, 2012). The higher the confidence level of the individual, the higher the efficacy of self motivation is. Intrinsic motivation is also a strong desire to do the job due to personal interests, encouraged by the response about the importance of the task to him. It is encouragement or pressure arising from within oneself in the form of satisfaction or completeness effectively. Intrinsic motivation can be traced through the desire to engage in the task voluntarily.

Extrinsic motivation is the desire to do jobs and to receive a reward from others or receive external rewards in the form of material or non-material. To achieve this motivation, an individual should be informed of the external reward. In short, extrinsic motivation is motivation that is realized through external rewards given after a job/assignment has been perfectly done. Next, social motivation is the desire to share and apply the knowledge and skills with others while performing the task. Individuals who shared knowledge will feel great satisfaction and pride in themselves, and in turn will encourage him to do the job continuously. According to Wigfield and Guthrie (1997), the combination of these four categories of motivation will result in maximum productivity.

Based on the above discussion, this study aims to (1) review the practices of the feedback environment by the perception of school middle leaders, (2) review of job motivation perceived by school middle leaders (3) study the relationship of feedback environment with job motivation among the school middle leaders and (5) identify the difference between feedback environment and job motivation among the middle leaders based on gender.

\section{Research Methodology}

\subsection{Research Design}

Cooper and Schindler (2001) has described the study design as a plan based on time, research questions, the selection of sources and types of information, framework for explaining the relationship between the study variables and procedures of the study. So, in answer to the objectives of this study, quantitative methods which are based on questionnaire surveys have been used. The selection is in line with the views of Gay, Mills, and Tiger (2006) that the quantitative study design is suitable for a large population because of the uniformity of the facts and information can be translated from the respondents. In fact, this method is also important to provide information on the current situation, identifying relationship, and the phenomenon of causation (Gay et al., 2006). 


\subsection{Population and Sampling}

James, Joe, and Chadwick (2011) has described the goal of the study is to collect data representing a population. Accordingly, Johnson and Christensen (2004) also describes the sample as a group from which information is obtained while the population refers to a larger group from which the sample was obtained. In this study, the study population comprised of subject coordinators who are placed in fifteen secondary schools in South Kinta, Perak. The study involved 63 subject coordinators who were randomly selected from the population of secondary schools in the area.

\subsection{Sample Profile}

The sample consisted of 63 subject coordinators of secondary schools in South Kinta, Perak Darul Ridzuan, Malaysia. A descriptive analysis of frequencies and percentages were used to describe the profile of respondents include gender, age, highest academic qualifications and employment experiences.

Table 1. Respondent profile

\begin{tabular}{|l|l|c|c|}
\hline Variable & Category & Frequency & Percentage \\
\hline \multirow{3}{*}{ Gender } & Male & 9 & 14.3 \\
\cline { 2 - 4 } & Female & 54 & 85.7 \\
\hline \multirow{3}{*}{ Highest Academic } & Degree & 52 & 82.5 \\
\cline { 2 - 4 } & Master & 11 & 17.5 \\
\hline \multirow{5}{*}{ Age } & 1 to 10 years & 45 & 71.4 \\
\cline { 2 - 4 } & 11 to 20 years & 7 & 17.5 \\
\cline { 2 - 4 } & 21 to 30 years & 22 & 11.1 \\
\hline & 26 to 32 years & 15 & 34.9 \\
\cline { 2 - 4 } & 33 to 39 years & 12 & 23.8 \\
\cline { 2 - 4 } & 40 to 46 years & 14 & 22.2 \\
\cline { 2 - 4 } & 47 to 53 years & 79.0 \\
\hline
\end{tabular}

\subsection{Research Instrument}

Data collected by cross-section which is collection of data at a time, using a questionnaire (Babbie, 2013). Cohen, Manion and Morrison (2008) also describes the cross-sectional design is used in studies involving the collection of data from a variety of variables and sample large sample scattered geographically. This study used a questionnaire which was adapted from existing instruments and have been used by previous researchers. The questionnaire was divided into three parts, Part A (4 items) to obtain demographic data of the sample, Part B (25 items) to measure the feedback process in the work environment, and Part C (24 items) is on the job motivation of the middle leader. Part B has been adapted from Feedback Environment Scale developed by Steelman et al. (2004) to diagnose the feedback process that occurs in an organizational setting. In addition, Part $\mathrm{C}$ is designed to measure the motivation of middle leaders through four aspects of work motivation to adopt an instrument that has been used by Aribah (2014) and Wigfield and Guthrie (1995). Middle leaders in this study refers to the subject coordinators in school. The questionnaire study used a seven-point Likert scale. 


\subsection{Date Collection Procedures}

With the approval of the Ministry of Education, followed by Perak State Education Department and South Kinta District Education Department, data collection has begun. A total of 150 questionnaires were distributed and 63 manuscripts have been collected and used in the study with the 42 percent rate of return. All completed questionnaires were returned by each secondary school using the enclosed stamped envelope.

\subsection{Data Analysis}

This study used quantitative data analysis. The findings were collected and analyzed using Statistical Package Social Science (SPSS). At the first stage, a descriptive analysis was carried out to get an idea of the distribution of the sample and the variables of the study. Statistics mean and standard deviation were used to describe the variables of the study. Frequencies and percentages were used to describe the demographic characteristics of the teachers. Cronbach's alpha reliability test is used to determine the reliability of the instrument used. Based on the findings from Table 2 clearly demonstrated the reliability of this instrument is high and constant, Cronbach's alpha values obtained are within the range of 0.849 to 0.984 . In the second stage, inferential analysis was used to test the hypotheses of the study. To determine the relationship between feedback environment and job motivation among the school middle leaders, Spearman correlation analysis method was used. Next, to see the effect of feedback environment and job motivation on gender, Mann-Whitney U test was used.

Table 2. Reliability analysis of the instrument

\begin{tabular}{|l|c|}
\hline Variable & Alpha Cronbach \\
\hline Feedback Environment & .984 \\
\hline Feedback source credibility & .947 \\
\hline Feedback quality & .972 \\
\hline Feedback delivery & .942 \\
\hline Feedback source availability & .917 \\
\hline Constructive feedback & .947 \\
\hline Encourage feedback seeking & .857 \\
\hline Job Motivation & .957 \\
\hline Self-efficacy & .904 \\
\hline Intrinsic & .849 \\
\hline Extrinsic & .924 \\
\hline Social motivation & .965 \\
\hline
\end{tabular}

Kolmogorov-Sminov test was carried out to identify whether there is a normal distribution of data by gender. The findings of the research is as shown below:

Table 3. Kolmogorov-Sminov test result

\begin{tabular}{|l|l|c|c|c|}
\hline Particular & Group & Statistics & $\boldsymbol{d} \boldsymbol{f}$ & Significance \\
\hline \multirow{2}{*}{ Gender } & Male & .954 & 9 & $.736^{*}$ \\
\cline { 2 - 5 } & Female & .943 & 54 & .012 \\
\hline
\end{tabular}

Note: *Significant at the level of $p<0.05$ 
The findings of the above table demonstrated the score distribution of feedback environment for all groups by gender is not normal except for the male. Hence, the parametric test for comparison between groups by gender is inappropriate.

Hence, the parametric test for comparison between groups by gender is inappropriate. Therefore, the Mann-Whitney U test was used to test whether there are significant differences between the groups by gender. Next, Spearman correlation test was used to identify significant associations between feedback environment and motivation among the school middle leaders. Data analysis methods used for this study are shown in Table 4.

Table 4. Data analysis methods for each objective of the study

\begin{tabular}{|c|c|c|}
\hline Item & Types of Analysis & Test Instrument \\
\hline 1 & Identify respondents' background. & Total, percentage \\
\hline 2 & Determine whether the data is normally distributed. & Kolmogorov-Smirnov Test \\
\hline 3 & Assessing feedback environment practices in the workplace. & Mean, standard deviation \\
\hline 4 & Level of feedback environment by dimensions. & $\begin{array}{c}\text { Mean score, } \\
\text { standard deviation }\end{array}$ \\
\hline \multirow[t]{2}{*}{5} & Assessing job motivation among the school middle leaders. & Mean, standard deviation \\
\hline & Level of job motivation by dimensions. & $\begin{array}{c}\text { Mean score, } \\
\text { standard deviation }\end{array}$ \\
\hline 6 & $\begin{array}{l}\text { Determine the relationship between feedback environment and job } \\
\text { motivation among the school middle leaders. }\end{array}$ & Spearman Correlation Test \\
\hline 7 & $\begin{array}{l}\text { Determine the relationship between feedback environment and job } \\
\text { motivation among the school middle leaders according to the } \\
\text { dimensions. }\end{array}$ & Spearman Correlation Test \\
\hline 8 & $\begin{array}{l}\text { Identify whether there are significant differences between feedback } \\
\text { environment between male and female middle leaders. }\end{array}$ & Mann-Whitney U Test \\
\hline 9 & $\begin{array}{l}\text { Identify whether there are significant differences between job } \\
\text { motivation and the gender of middle leaders. }\end{array}$ & Mann-Whitney U Test \\
\hline
\end{tabular}

\section{Research Findings}

\subsection{Descriptive Analysis of Feedback Environment Practice Items in the Workplace}

The findings have shown there are 22 items that 88 per cent of the items recorded a high level of effectiveness while only 3 items at 12 per cent on medium-high level. This clearly shows that respondents showed a high response on the feedback environment practice as the majority of the items fall into the category of high level. This can be seen through B6 item of "I appreciate the feedback received from my leaders" with the highest mean score of 6.03 $(\mathrm{S} . \mathrm{D}=.861)$. In comparison between items, item B15 that "I always receive praises from my leaders" obtained the lowest mean score of $30.5(\mathrm{~S} . \mathrm{D}=.1 .265)$. 
Table 5. The mean value and standard deviation of feedback environment practice items

\begin{tabular}{|c|c|c|c|}
\hline No. & Item & Mean & S.D \\
\hline $\mathrm{B} 1$ & I am confident with the feedback given by my leaders. & 5.79 & .900 \\
\hline B2 & My leaders act fairly when assessing my work. & 5.62 & .991 \\
\hline B3 & Generally, I respect my leaders' opinion about my performance. & 5.86 & .931 \\
\hline B4 & My leaders are very helpful when giving feedback on my work performance. & 5.73 & 1.003 \\
\hline B5 & My leaders are familiar with my work performance. & 5.62 & 1.007 \\
\hline B6 & I appreciate the feedback received from my leaders. & 6.03 & .861 \\
\hline B7 & $\begin{array}{l}\text { The feedback on the performance of my work received from my leaders, are a } \\
\text { great help. }\end{array}$ & 5.94 & .948 \\
\hline B8 & My leaders provide useful feedback on my performance. & 5.94 & .859 \\
\hline B9 & $\begin{array}{l}\text { The feedback I have received from my leaders helped me to carry out my } \\
\text { duty. }\end{array}$ & 5.92 & .885 \\
\hline B10 & My leaders are wise when providing feedback on my performance. & 5.71 & .974 \\
\hline B11 & My leaders always respond prudently. & 5.97 & .897 \\
\hline B12 & My leaders treat me well when giving feedback. & 5.92 & .885 \\
\hline B13 & $\begin{array}{l}\text { The information on my work performance received from my leaders is } \\
\text { meaningful to me. }\end{array}$ & 5.98 & .852 \\
\hline B14 & Based on the feedback on my work performance, I usually trust my leaders. & 5.86 & .965 \\
\hline B15 & I always receive praises from my leaders. & 5.30 & 1.265 \\
\hline B16 & $\begin{array}{l}\text { When I ask for feedback on work performance, my leaders will address to it } \\
\text { directly. }\end{array}$ & 5.62 & .991 \\
\hline B17 & My leaders are glad when I ask for feedback on my work performance. & 5.63 & .989 \\
\hline B18 & I am always in touch with my leaders. & 5.71 & .869 \\
\hline B19 & My leaders have time to respond to me. & 5.70 & .775 \\
\hline $\mathrm{B} 20$ & Normally, my leaders will inform me if I have done a good job. & 5.60 & .925 \\
\hline $\mathrm{B} 21$ & I often receive positive feedback from my leaders. & 5.78 & .792 \\
\hline $\mathrm{B} 22$ & My leaders praise me when I do my work well. & 5.63 & 1.021 \\
\hline B23 & $\begin{array}{l}\text { In certain circumstances, when my performance dropped from its } \\
\text { expectations, my leaders would inform me. }\end{array}$ & 5.41 & .961 \\
\hline B24 & $\begin{array}{l}\text { I feel comfortable when asking for feedback on my work performance from } \\
\text { my leaders. }\end{array}$ & 5.46 & 1.013 \\
\hline B25 & $\begin{array}{l}\text { My leaders encourage me to get a response if I am not sure with my work } \\
\text { performance. }\end{array}$ & 5.60 & .943 \\
\hline
\end{tabular}

Note: S.D = Standard Deviation

Descriptive analysis of the study in Table 6 found that school leaders formed high level of feedback environment which is between the mean value of 5.30 to 6.03 , based on the perception of middle leaders in schools. This study used a 7-point Likert scale because it is identified as more sensitive to the feelings of the respondents (Alwin, 1997). In interpreting the findings, mean scores of 1.00 and 2.50 are classified as low-level, mean scores between 2:51 to 4:00 categorized as medium-low, mean scores between 4:01 to 5:50 categorized as 
medium-high level, and the mean scores between 5:51 to 7:00 categorized as a high level.

Table 6 shows the level of feedback environment based on the dimensions according to the views of school middle leaders. Dimensions of feedback environment that are listed in the following table have been compiled in order, from the highest score to the lowest score. The findings indicate dimensions of quality feedback received the highest mean score 5.91 (SD $=.856$ ) while dimension of promoting feedback seeking among the middle leaders last with a mean score of $5.53(\mathrm{SD}=.920)$. Overall, the average mean score for feedback environment in accordance with the opinion of middle leaders only as high as 5.71 (SD $=.798)$.

Table 6 . The level of feedback environment by the dimensions

\begin{tabular}{|l|c|c|c|}
\hline Dimension & Mean Score & S.D & Level \\
\hline Feedback Environment & 5.71 & .798 & High \\
\hline Feedback quality & 5.91 & .856 & High \\
\hline Feedback delivery & 5.81 & .881 & High \\
\hline Feedback source credibility & 5.72 & .878 & High \\
\hline Feedback source availability & 5.67 & .812 & High \\
\hline Constructive feedback & 5.61 & .854 & High \\
\hline Encourage feedback seeking & 5.53 & .920 & High \\
\hline
\end{tabular}

\subsection{Descriptive Analysis of Job Motivation of School Middle Leaders Items}

Referring to Table 7, the results have shown that there are 19 items which recorded 79.2 percent for mean score at high levels while only five items, namely 20.8 percent in the moderately-high level. This clearly shows that respondents showed a high level of motivation as the majority of the items fall into the category of high level. This can be seen through the C24 item "I consider the view of my subordinate staff is crucial in achieving the mission and vision of the school" with the highest mean score of 29.6 ( $\mathrm{SD}=.633)$. In comparison between items, item C3 of "My contribution to the excellence of my school is great" obtained the lowest mean score of $5.32(\mathrm{SD}=.1 .075)$.

Descriptive analysis of the study in Table 8 found that school middle leaders are highly motivated with the score mean between the mean value 5.47 to 6.23 . The study shows that the aspect of social motivation is the most dominant aspect of the population of South Kinta in this study with the mean score as high as 6.23 ( $\mathrm{SD}=.657)$. This means the level of social motivation among the respondents is very high. The school middle leaders in this study often share ideas, opinions, and information and skills with either principal or subordinate staff. Middle leaders in this study had a desire to share knowledge and skills with others to achieve the satisfaction of himself and pushing himself to achieve the set targets on an ongoing basis.

A further aspect of motivation namely extrinsic motivation with a mean of $14.6(\mathrm{SD}=.676)$. This was followed by an intrinsic motivation aspect which has a high mean of 5.91 $(\mathrm{SD}=.667)$. The mean score of self-efficacy motivation dimension is the lowest among the four aspects of the motivation of 5.47 ( $\mathrm{SD}=.769)$. Overall, the motivation for the middle group of leaders in this study was as high as $5.93(\mathrm{SD}=.576)$. 
Table 7. The mean value and standard deviation of job motivation practices item

\begin{tabular}{|c|c|c|c|}
\hline No. & Item & Min & S.D \\
\hline $\mathrm{C} 1$ & I run a very efficient management work. & 5.71 & .771 \\
\hline $\mathrm{C} 2$ & I am able to influence my subordinate staff effectively. & 5.37 & .891 \\
\hline $\mathrm{C} 3$ & My contribution to the excellence of my school is great. & 5.32 & 1.075 \\
\hline $\mathrm{C} 4$ & I am a good role model to my staff. & 5.41 & .873 \\
\hline $\mathrm{C} 5$ & I am confident with my leadership. & 5.52 & .913 \\
\hline C6 & I need to guide my subordinate staff to perform well. & 5.43 & .979 \\
\hline $\mathrm{C} 7$ & I always think of the most effective way to enhance my career. & 6.03 & .782 \\
\hline $\mathrm{C} 8$ & I try to perform better than my counterparts. & 5.95 & .851 \\
\hline C9 & $\begin{array}{l}\text { I consider my job at the school is the responsibility that should be } \\
\text { implemented the best I could. }\end{array}$ & 6.29 & .728 \\
\hline $\mathrm{C} 10$ & I have my own personal interest in my job at school. & 5.10 & 1.924 \\
\hline $\mathrm{C} 11$ & $\begin{array}{l}\text { I do not hesitate to attend any professional development courses for my } \\
\text { career development. }\end{array}$ & 5.89 & .900 \\
\hline $\mathrm{C} 12$ & $\begin{array}{l}\text { My ambition is to improve the school performance to the level of } \\
\text { excellence. }\end{array}$ & 6.22 & .706 \\
\hline $\mathrm{C} 13$ & I am happy when my work is recognized. & 6.29 & .728 \\
\hline $\mathrm{C} 14$ & $\begin{array}{l}\text { I consider the recognition as a booster to enhance the excellence of my } \\
\text { career. }\end{array}$ & 6.21 & .765 \\
\hline $\mathrm{C} 15$ & $\begin{array}{l}\text { I always give praise or recognition for excellent work performance of my } \\
\text { subordinate staff. }\end{array}$ & 6.08 & .747 \\
\hline $\mathrm{C} 16$ & I think my promotion should commensurate with my efforts in school. & 6.03 & .822 \\
\hline $\mathrm{C} 17$ & I think, by giving promotion to me will improve my performance. & 6.05 & .812 \\
\hline $\mathrm{C} 18$ & I am very happy if my school is recognized as an outstanding school. & 6.19 & .800 \\
\hline C19 & $\begin{array}{l}\text { I give credence to the teachers to perform their duties according to their } \\
\text { abilities. }\end{array}$ & 6.21 & .722 \\
\hline $\mathrm{C} 20$ & I am proud to share my expertise with my subordinate staff. & 6.21 & .744 \\
\hline $\mathrm{C} 21$ & $\begin{array}{l}\text { I believe that a good working environment can enhance my subordinate } \\
\text { staff work performance. }\end{array}$ & 6.27 & .766 \\
\hline $\mathrm{C} 22$ & I like working with staff who like to discuss with me. & 6.25 & .761 \\
\hline $\mathrm{C} 23$ & $\begin{array}{l}\text { The suggestions for improvement from my subordinate staff, is a major } \\
\text { booster to my working spirit. }\end{array}$ & 6.14 & .644 \\
\hline $\mathrm{C} 24$ & $\begin{array}{l}\text { I consider the view of my subordinate staff is crucial in achieving the } \\
\text { mission and vision of the school. }\end{array}$ & 6.29 & .633 \\
\hline
\end{tabular}

Note: S.D = Standard Deviation

According to the theory put forward by Wigfield and Guthrie (1997), it explains human motivation is often influenced by working environmental factor which shows a very high motivation. An encouraging working environment climate will stimulate individuals to achieve excellence. Accordingly, Dunning (2007) also describes the social motivation stemmed from the social factors that shape the humanitarian responsibilities of leaders and the aspects that make up the social motivation of common, mutual help, using influence and 
power. These findings also support the arguments of Lim and Poon (1997), as well as Seibert, Kraimer and Crant (2001). Reviews from Lim and Poon (1997) showed that teachers who have commitment, effort and high performance are those with high self-efficacy and motivation. In addition, Seibert, Kraimer, and Crant (2001) reported that self-efficacy guides the leaders to complete their tasks exceeding specified levels and continue to aspire in order to fulfill the highest achievement. Therefore, these findings obviously demonstrate the importance of motivation in improving the performance of educational organizations.

Table 8 . Level of job motivation by dimensions

\begin{tabular}{|l|c|c|c|}
\hline Dimensions & Min Score & S.D & Level \\
\hline Working motivation & 5.93 & .576 & High \\
\hline Social motivation & 6.23 & .657 & High \\
\hline Extrinsic & 6.14 & .676 & High \\
\hline Intrinsic & 5.91 & .667 & High \\
\hline Self-efficacy & 5.47 & .769 & High \\
\hline
\end{tabular}

6.3 The Relationship between Feedback Environment and Job Motivation among Middle School Leaders

Further analysis was performed using Spearman correlation test to determine the relationship between the dimensions of feedback environment with job motivation among the school middle leaders. The results presented in Table 9 and Table 10.

Spearman correlation analysis test results in Table 9 showed a significant relationship between the six dimensions of feedback environment and job motivation. The results showed a strong correlation between the feedback quality with motivation $(r=.659, \mathrm{p}<.05)$, availability of feedback source $(r=.670, p<.05)$, and feedback delivery $(r=.636, p<.05)$. These findings demonstrate the need for school leaders to create a channel for providing feedback to the middle leaders consistently and continuously.

In addition, the reliability of the feedback source credibility $(\mathrm{r}=.599, \mathrm{p}<.05)$, constructive feedback $(\mathrm{r}=.638, \mathrm{p}<.05)$, and encourage feedback seeking $(\mathrm{r}=.583, \mathrm{p}<.05)$ were found to have a significant and positive with job motivation in school.

The results in Table 8 shows the relationship between the six-dimensional feedback environment and four aspects of job motivation in details. It shows the four aspects of self-efficacy motivation, intrinsic, extrinsic, social motivation and have a positive and significant relationship with the feedback environment. Overall, the findings of this study show school leaders practice feedback environment in encouraging job motivation among the school middle leaders. 
Table 9. The correlation between feedback environment and job motivation among school middle leaders

\begin{tabular}{|l|c|}
\hline Feedback Environment Dimension & Job Motivation \\
\hline Feedback quality & $.659^{*}$ \\
\hline Feedback availability & $.670^{*}$ \\
\hline Feedback delivery & $.621^{*}$ \\
\hline Feedback reliability & $.599^{*}$ \\
\hline Constructive feedback & $.638^{*}$ \\
\hline Encourage feedback search & $.583^{*}$ \\
\hline
\end{tabular}

Note: *At the significance level $p<.05$

Table 10. The correlation between feedback environment and job motivation among school middle leaders according to dimensions

\begin{tabular}{|c|c|c|c|c|c|c|c|c|c|}
\hline & FR & FQ & FD & FA & CF & EFS & SE & ITS & EXS \\
\hline FQ & $.835^{*}$ & & & & & & & & \\
\hline FD & $.836^{*}$ & $.857^{*}$ & & & & & & & \\
\hline FA & $.762^{*}$ & $.785^{*}$ & $.852^{*}$ & & & & & & \\
\hline CF & $.716^{*}$ & $.767 *$ & $.850^{*}$ & $.870^{*}$ & & & & & \\
\hline EFS & $.716^{*}$ & $.739^{*}$ & $.785^{*}$ & $.829 *$ & $.890^{*}$ & & & & \\
\hline SE & $.418^{*}$ & $.411^{*}$ & $.437^{*}$ & $.486^{*}$ & $.554^{*}$ & $.535^{*}$ & & & \\
\hline ITS & $467^{*}$ & $.539^{*}$ & $.490^{*}$ & $.521^{*}$ & $.433^{*}$ & $.456^{*}$ & $.445^{*}$ & & \\
\hline EXS & $.545^{*}$ & $.580^{*}$ & $.545^{*}$ & $.600^{*}$ & $.538^{*}$ & $.470^{*}$ & .580 & $.727 *$ & \\
\hline SM & $.523^{*}$ & $.600^{*}$ & $.559^{*}$ & $.559^{*}$ & $.519^{*}$ & $.481^{*}$ & $.409^{*}$ & $.557^{*}$ & $.806^{*}$ \\
\hline
\end{tabular}

Note: *At the significance level $p<.05$

Feedback reliability (FR), Feedback quality (FQ), Feedback delivery (FD), Feedback availability (FA), Constructive feedback (CF), Encourage feedback search (EFS), Self-efficacy (SE), Intrinsic (ITS), Extrinsic (EXS), Social motivation (SM)

\subsection{The Difference between Feedback Environment Practices with Gender}

The results of the Mann-Whitney U test showed there was no significant difference between the responses for the feedback environment on gender of middle leaders at school at significant level $\mathrm{p}<.05(\mathrm{Z}=-.609, \mathrm{p}=.542)$. This means both male and female exhibiting the same level of feedback environment.

\subsection{The Difference between Job Motivation Practices with Gender}

The results of the Mann-Whitney $U$ test showed overall there was no significant difference in job motivation on the gender at a significant level of $\mathrm{p}<.05(\mathrm{Z}=-.242, \mathrm{p}=.809)$. This means both male and female genders exhibit the same level of job motivation.

\section{Research Implication and Conclusion}

Through this research, school leaders can recognize the level of feedback environment and job motivation among the middle leaders of the school. In addition, these findings provide information about the feedback environment practices and job motivation among the school 
middle leaders in an effort to design and develop programmes that should be given to groups of middle leaders so that they can play a more effective role.

In addition, these findings bring awareness to the school principal that the role of subject coordinators as middle leaders in school should not be underestimated because they are the group that is the closest to the teachers. They are influencing the self-efficacy of teaching among the followers. Thus, highly motivated middle leaders will be effective in ensuring continued teaching duties. This is because the subordinate staff will see their middle leaders as role models. Indirectly, these findings also emphasize the school principal should create feedback environment that helps to develop, lead and motivate followers to achieve organizational goals.

The results of this study imply that in order to establish the quality of human capital to meet the market, the principal is responsible for creating feedback environment that encourages feedback at work. A climate that encourages the delivery of feedback based on followers' strengths will encourage high motivation especially among school middle leaders. School leaders must not only give feedback on the performance of the middle leaders but they have to deliver feedback both informally and consistently. In addition, school leaders should encourage their followers to act actively in seeking feedback. This will increase productivity and organizational effectiveness.

\section{References}

Aguinis, H., Gottfredson, R. K., \& Joo, H. (2012). Delivering effective performance feedback: The strengths-based approach. Business Horizons, 55, 105-111. http://dx.doi.org/10.1016/j.bushor.2011.10.004

Aribah, I. (2014). Kecerdasan pelbagai dan motivasi kerja pemimpin sekolah. In Y. P. Chua (Ed.), Kecerdasan pelbagai pemimpin pendidikan. Teori, amalan dan penyelidikan. (pp. 33-54). Kuala Lumpur: Penerbit Universiti Malaya.

Babbie, E. (2013). The practice of social research. (13th ed.). Wadsworth, Belmont.

Bandura, A. (1986). Social foundations of thought and action: A social cognitive theory. Englewood Cliffs, NJ: Prentice-Hall

Chua, Y. P. (2012). Buku 2: Effect of computer-based testing on test performance and test motivation. Computers in Human Behavior, 28(5), 1580-1586. http://dx.doi.org/10.10 16/j.chb.2013.03.008

Cohen, L., Manion, L., \& Morrison, K. (2008). Research methods in education. (6th ed.). Routledge, New York.

Cooper, D. R., \& Schindler, P. S. (2001). Business research methods (7th ed.). New York: McGraw-Hill Irwin.

Gay, L. R., Mills, G. E., \& Airasian, P. (2006). Educational research: Competencies for analysis and applications (8th ed.). New Jersey: Pearson Education. 
Geddes, D., \& Linnehan, F. (1996). Exploring the dimensionality of positive and negative performance feedback. Communication Quarterly, 44(3), 326-344. http://dx.doi.org/10. 1080/01463379609370021

Hattie, J., \& Timperley, H. (2007). The power of feedback. Review of Educational Research, 77(1), 81-112. http://dx.doi.org/10.3102/003465430298487

Ilgen, D. R., \& Davis, C. A. (2000). Bearing bad news: Reactions to negative performance feedback. Applied Psychology: An International Review, 49(3), 550-565.

Ilgen, D. R., \& Moore, C. F. (1987). Types and choices of performance feedback. Journal of Applied Psychology, 72(3), 401-406.

James, E. B., Joe, W. K., \& Chadwick, C. H. (2001). Organizational research: Determining appropriate sample size in survey research. Informational Technology, Learning and Performance Journal, 19(1), 43-50.

Jex, S. M., \& Britt, T. W. (2008). Organizational psychology. A scientist-practitioner approach (2nd ed.). New Jersey: John Wiley \& Sons, Inc.

Johnson, R. B., \& Christensen, L. B. (2013). Educational research: Quantitative, qualitative, and mixed approaches (5th ed.). Thousand Oaks, California: Sage.

Kluger, A. N., \& DeNisi, A. (1996). The effects of feedback interventions on performance: A historical review, a meta-analysis and a preliminary feedback intervention theory. Psychological Bulletin, 119(2), 255-284.

Makiney, J. D., \& Levy, P. E. (1998). The influence of self-ratings versus peer ratings on supervisors' performance judgments. Organizational Behavior and Human Decision Processes, 74(3), 212-228.

Moore, W. P., \&Esselman, M. E., (1992). Teacher efficacy, empowerment, and a focused instructional climate: Does student achievement benefit? Paper presented at the annual meeting of the American Educational Research Association, San Francisco.

Norris-Watts, C., \& Levy, P. E. (2004). The mediating role of affective commitment in the relation of the feedback environment to work outcomes. Journal of Vocational Behavior, 65(3), 351-365. http://dx.doi.org/10.1016/j.jvb.2003.08.003

Nurul Jalilah Binti Abdul Rahman. (2013). Pengaruh gaya kepimpinan pengetua terhadap tahap motivasi guru sekolah menengah di Zon Bandar Segamat. Tesis Sarjana Pendidikan yang tidak diterbitkan. Universiti Teknologi Malaysia, Johor.

Rosen, C. C., Levy, P. E., \& Hall, R. J. (2006). Placing perceptions of politics in the context of the feedback environment, employee attitudes, and job performance. Journal of Applied Psychology, 91(1), 211-220. http://dx.doi.org/10.1037/0021-9010.91.1.211

Steelman, L. A., Levy, P. E., \& Snell, A. F. (2004). The feedback environment scale: Construct definition, measurement, and validation. Educational and Psychological Measurement, 64(1), 165-184. http://dx.doi.org/10.1177/0013164403258440 


\section{Macrothink}

Tschannen-Moran, M., \& Hoy, A. W. (2001). Teacher efficacy: Capturing an elusive construct. Teaching and Teacher Education, 17, 783-805.

Wigfield, A., \& Guthrie, J. T. (1997). Relations of children's motivation for testing to the amount and breath of their testing. Journal of Educational Psychology, 89, 420-432.

Williams, J. R., Miller, C., Steelman, L. A., \& Levy, P. E. (1999). Increasing feedback seeking in public contexts: It takes two (or more) to tango. Journal of Applied Psychology, 84(6), 969-976.

Yanagizawa, S. (2008). Effect of goal difficulty and feedback seeking on goal attainment and leaving. Japanese Psychological Research, 50(3), 137-144.

\section{Copyright Disclaimer}

Copyright reserved by the author(s).

This article is an open-access article distributed under the terms and conditions of the Creative Commons Attribution license (http://creativecommons.org/licenses/by/3.0/). 